\title{
Cold oceans enhance terrestrial new-particle formation in near-coastal forests
}

\author{
T. Suni ${ }^{1}$, L. Sogacheva ${ }^{1}$, J. Lauros ${ }^{1}$, H. Hakola ${ }^{2}$, J. Bäck ${ }^{3}$, T. Kurtén ${ }^{1}$, H. Cleugh ${ }^{4}$, E. van Gorsel ${ }^{4}$, P. Briggs ${ }^{4}$, \\ S. Sevanto ${ }^{1}$, and M. Kulmala ${ }^{1}$ \\ ${ }^{1}$ Department of Physics, University of Helsinki, P.O. Box 48, 00014 Helsinki, Finland \\ ${ }^{2}$ Finnish Meteorological Institute, P.O. Box 503, 00101 Helsinki, Finland \\ ${ }^{3}$ Department of Forest Ecology, P.O. Box 27, 00014 University of Helsinki, Finland \\ ${ }^{4}$ CSIRO Marine and Atmospheric Research, GPO Box 1666, Canberra ACT 2601, Australia
}

Received: 3 April 2009 - Published in Atmos. Chem. Phys. Discuss.: 11 June 2009

Revised: 14 October 2009 - Accepted: 3 November 2009 - Published: 16 November 2009

\begin{abstract}
The world's forests produce atmospheric aerosol by emitting volatile organic compounds (VOC) which, after being oxidized in the atmosphere, readily condense on the omnipresent nanometer-sized nuclei and grow them to climatically relevant sizes. The cooling effect of aerosols is the greatest uncertainty in current climate models and estimates of radiative forcing. Therefore, identifying the environmental factors influencing the biogenic formation of aerosols is crucial. In this paper, we connected biogenic aerosol formation events observed in a Eucalypt forest in South-East Australia during July 2005-December 2006 to air mass history using 96-h back trajectories. Formation of new particles was most frequent in the dry westerly and south-westerly air masses. According to NDVI (Normalized Difference Vegetation Index) measurements, photosynthesis was not significantly higher in this direction compared to the north-east direction. It is unlikely, therefore, that differences in photosynthesis-derived organic precursor emissions would have been significant enough to lead to the clear difference in NPF frequency between these two directions. Instead, the high evaporation rates above the Pacific Ocean resulted in humid winds from the north-east that effectively suppressed new-particle formation in the forest hundreds of kilometers inland. No other factor varied as significantly in tune with new-particle formation as humidity and we concluded that, in addition to local meteorological factors in the forest, the magnitude of evaporation from oceans hundreds of kilometers upwind can effectively suppress or enhance new-
\end{abstract}

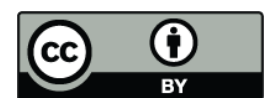

Correspondence to: T. Suni (tanja.suni@helsinki.fi) particle formation. Our findings indicate that, unlike warm waters, the cold polar oceans provide excellent clean and dry background air that enhances aerosol formation above nearcoastal forests in Fennoscandia and South-East Australia.

\section{Introduction}

The direct and indirect effects of aerosol particles on climate are the largest uncertainty in current climate models and estimates of radiative forcing (Baker and Peter, 2008; Clement et al., 2009). Aerosols are produced by human activity but they are also formed naturally in oceans, deserts, and forests. Vegetation emits volatile organic compounds (VOC) such as monoterpenes that, once oxidised in the atmosphere, readily condense on freshly nucleated nanometer-sized particles and participate in growing them to cloud condensation nucleus $(\mathrm{CCN})$ sizes $(50-100 \mathrm{~nm})$. The role of VOCs in biogenic particle formation has been known for a long time and it has been described in several previous studies (Kulmala et al. 2004; Atkinson, 2000; Calogirou et al., 1999). During the last decade, new-particle formation (NPF), the production of new aerosol particles by nucleation and subsequent nuclei growth, has proved to be a frequent phenomenon that takes place in most atmospheric environments and is able to affect particle number concentrations at regional and even global scales (Kulmala et al., 2004; Spracklen et al., 2006). Newly formed particles regularly grow to $\mathrm{CCN}$ sizes influencing cloud properties and thereby the Earth's radiative balance and climate (Wang et al., 2008; Anttila and Kerminen, 2008; Kerminen et al., 2005; Laaksonen et al., 2005; Kurtén et al., 2003). Determining the frequency and driving factors

Published by Copernicus Publications on behalf of the European Geosciences Union. 

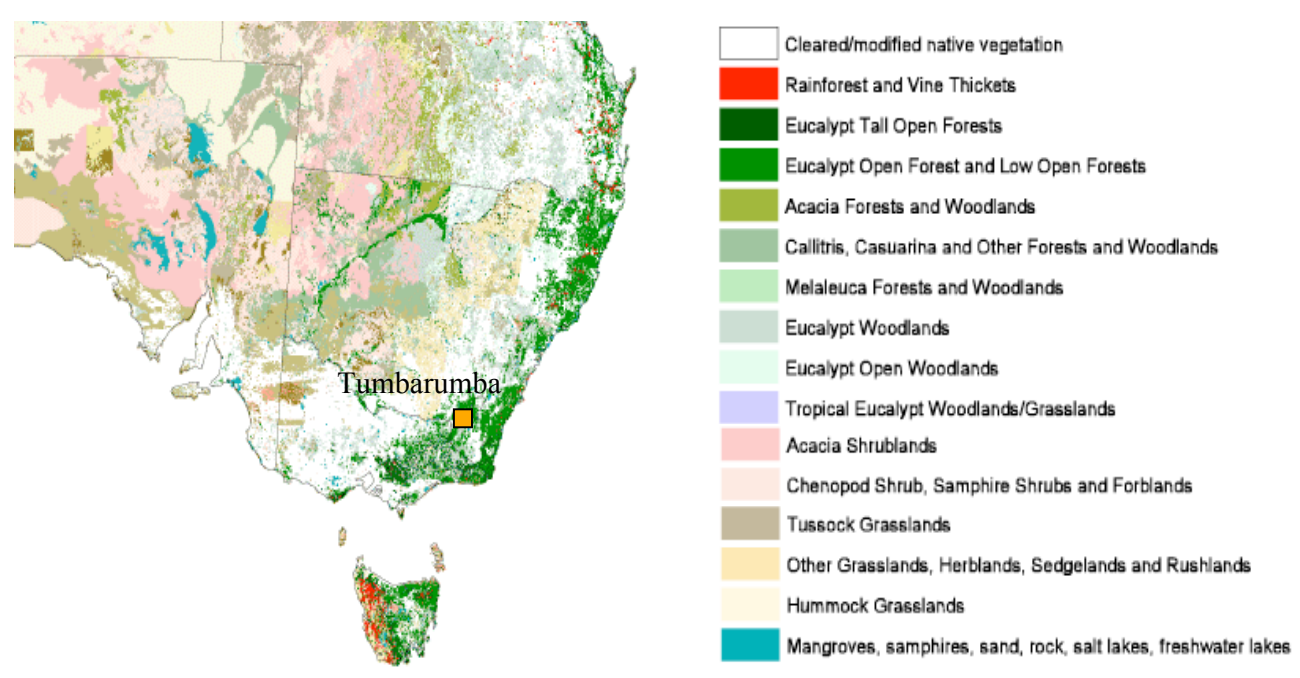

Fig. 1. Some major vegetation groups in South-East Australia. Source: National Land and Water Resources Audit 2001. Copyright: Commonwealth of Australia 2001. http://audit.ea.gov.au/ANRA/vegetation/docs/Native_vegetation/nat_veg_fig8_popup.cfm.

of biogenic aerosol production in different ecosystems is crucial for the future development of climate models. However, despite several attempts to identify the main environmental factors affecting biogenic new-particle formation, the evidence is still largely controversial.

Water vapor affects the biological, physical, and chemical aspects of particle formation. High relative humidity ( $\mathrm{RH}$ ) is often linked with cloudy and rainy days with weak solar radiation and cool temperatures when new-particle formation is typically not observed (Nilsson et al., 2001; Buzorius et al., 2001; Suni et al., 2008). The emissions of terpenes, precursors of forest aerosols, are related to temperature and sometimes directly to solar radiation (Kesselmeier and Stadt, 1999). Also the production of $\mathrm{OH}$, an important atmospheric oxidant, is driven by solar radiation, so cloudy days lead to weaker terpene and $\mathrm{OH}$ production than sunny days. High humidity can also increase the condensational and coagulation sinks (CS and CoagS, respectively) formed by pre-existing larger particles. This pre-existing aerosol forms a large total surface that consumes condensable vapors and scavenges molecular clusters effectively. As a function of humidity, pre-existing particles grow hygroscopically increasing CS and CoagS and potentially suppress new particle formation (Hyvönen et al., 2005). Indeed, RH and preexisting aerosol particle surface have been shown to explain $88 \%$ of the new-particle formation events in a Finnish pine forest (Hyvönen et al., 2005).

The small concentration of pre-existing particles (low CS and CoagS) in the air arriving from the Arctic Ocean makes Arctic and Polar air masses very conducive to terrestrial aerosol formation once they collect condensable vapors while traveling above the boreal forest (Tunved et al., 2006). Determining the effects of other oceanic air properties such as temperature and humidity on aerosol formation
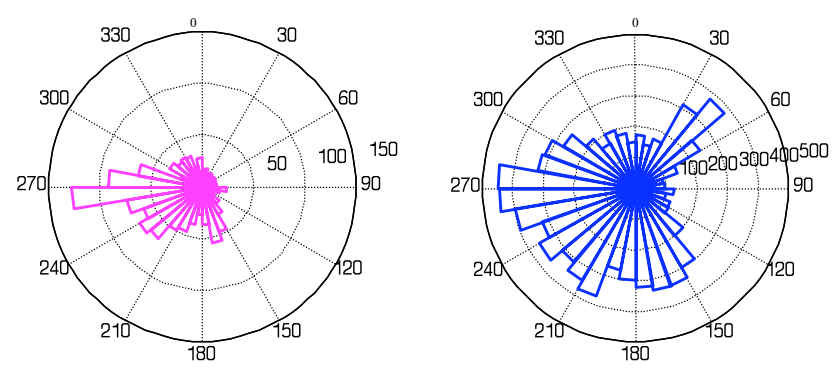

Fig. 2. Local wind direction during days with new-particle formation and during days with no clear formation. The frequency plot of local wind direction shows that the dominant wind direction during formation events (left) was west and south-west. During days with no clear formation (right), the wind direction distribution was much more even and, in particular, featured north-eastern winds from the Pacific Ocean. Time period: July 2005 to October 2006.

has been difficult because a rural field site close to two different oceans in directions equally free from anthropogenic influence would be necessary. Most sites are adjacent to only one sea or ocean in a pollution-free direction and even then they may be too close to the coast for inland aerosol formation studies (Mace Head at the coast of North Atlantic, Cape Grim at the coast of the Southern Ocean, Hyytiälä $\sim 1000 \mathrm{~km}$ from the Arctic Ocean). Finding a remote, forested field site close to two different oceans with contrasting characteristics is very difficult.

The Tumbarumba field station in South-East Australia meets those requirements and is therefore an excellent place to study the effect of air masses on aerosol formation, as indicated by the map in Fig. 1. The area is largely forested and faces the warm Pacific Ocean in the east and the cold Southern Ocean in the south. The site is remote and clean: 

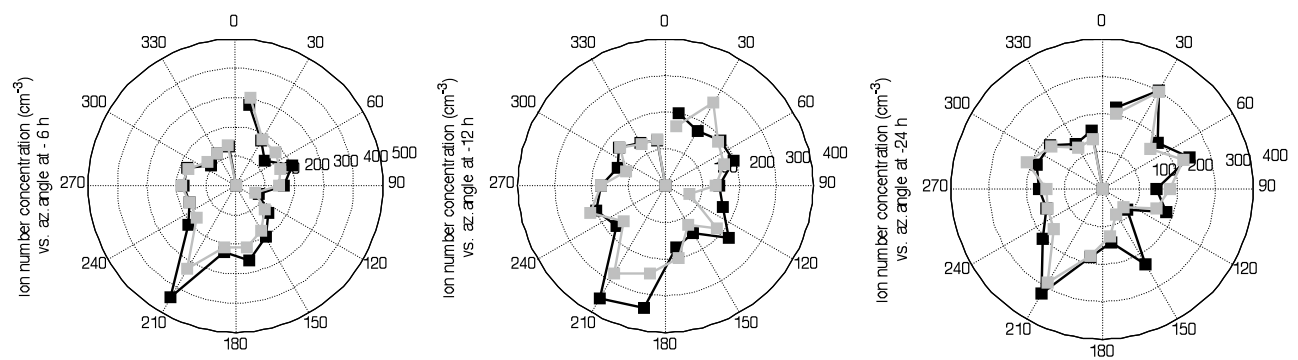

Fig. 3. Median number concentration of $2-14 \mathrm{~nm}$ ions as a function of trajectory direction. The number concentration is shown at (left) $6 \mathrm{~h}$ before arrival (middle) $12 \mathrm{~h}$ before arrival and (right) $24 \mathrm{~h}$ before arrival to Tumbarumba (11-16). Black - negative, grey - positive ions. The highest particle concentrations corresponded to days when air masses arrived rather directly from the south-west: the location of the air mass was in the south-west $6 \mathrm{~h}, 12 \mathrm{~h}$, and $24 \mathrm{~h}$ before the observed formation event instead of the wind circulating around the surrounding land areas.
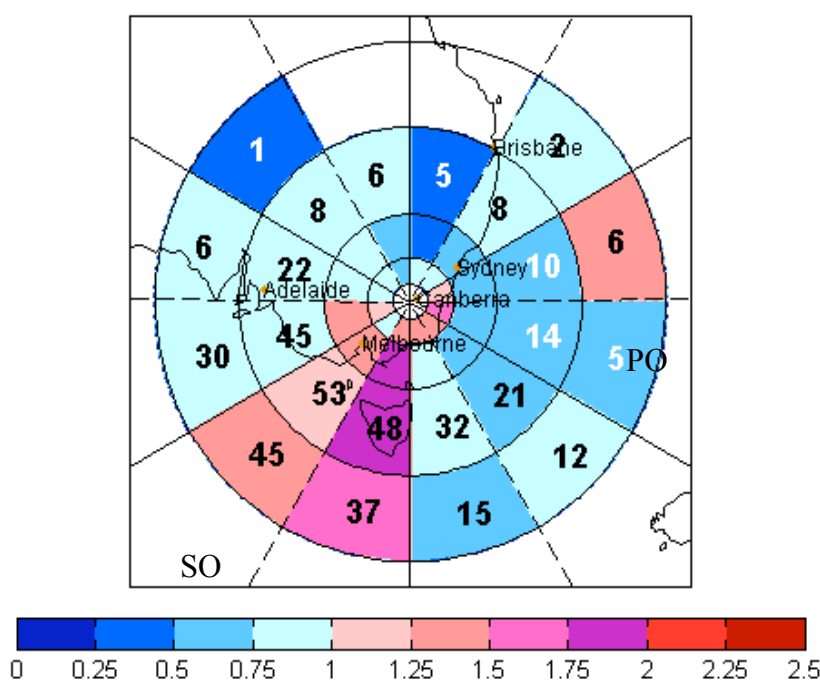

Fig. 4. Frequency of new-particle formation as a function of air mass arrival path in July 2005-December 2006. The figure inside each sector is the number of days with observed new-particle formation events for air masses that traveled through that particular sector $\left(n_{f}\right)$. For each sector, the color indicates the ratio $r=n_{f} / \mathrm{n}_{n}$ where $n_{n}$ is the number of days with no clear event.

the total ultrafine particle number concentration is approximately $1000 \mathrm{~cm}^{-3}$, about half of that at the SMEAR II station in Hyytiälä, southern Finland, also referred to as a remote site (Suni et al., 2008). Although oceans can affect nucleation at coastal areas by providing precursors, of which two well known ones are DMS and iodine, our measuring site is located $500 \mathrm{~km}$ from any coast. We have no direct measurements of the effect of DMS in particle formation in Tumbarumba but, with a lifetime of approximately $48 \mathrm{~h}$, DMS can certainly be transported several hundreds of kilometers inland. However, Ristovski et al. (2009) showed that the sulfate component in the particles collected in Tumbarumba in most cases was only $<6 \%$ of nucleation-mode particles and the majority of the growth was attributable to organic vapors emitted by the vegetation. Furthermore, Modini et al. (2009) found no trace of iodine in particles $(17-22.5 \mathrm{~nm})$ collected at Agnes Water, a remote tropical site at the coast of the Pacific Ocean. Finally, according to Tunved et al. (2006), the effect of the boreal forest is clearly observable in particle formation in air masses traveling from the Arctic Ocean inland during the first few hours of time on land already. Although the marine precursors are likely to have an effect on the growth of the particles, it seems to us, therefore, that their role must be minor compared to that of organic vapors emitted by the vegetation between the oceans and the Tumbarumba site.

The east and south coasts both have only two major cities with several million inhabitants, Sydney and Brisbane at the Pacific coast and Melbourne and Adelaide in the south. Otherwise the coastal population is small and the inlands are sparsely inhabited. Air masses arriving from both coasts travel first over an ocean and then over a mixture of agricultural fields, grasslands, pastures, and mountains covered mainly by Eucalypt forests. The Tumbarumba flux station is located in the center of the fertile forested mountains, half-way between Melbourne and Sydney. High frequencies of day- and night-time new-particle formation in the range $0.34-40 \mathrm{~nm}$ were observed there during July 2005-October 2006 (Suni et al., 2008). In this paper, we connect daytime formation events observed during July 2005-December 2006 to air mass history using 96-h back trajectories.

\section{Materials and methods}

\subsection{Site description}

The Tumbarumba flux station is located in the Bago State forest in south eastern New South Wales: $35^{\circ} 39^{\prime} 20.6^{\prime \prime} \mathrm{S}$, $148^{\circ} 09^{\prime} 07.50^{\prime \prime} \mathrm{E}$. The forest is classified as a tall open Eucalypt forest. The dominant species are E. delegatensis (Alpine Ash) and E. dalrympleana (Mountain Gum), and average tree height is $40 \mathrm{~m}$. Elevation of the site is $1200 \mathrm{~m}$; mean annual precipitation is $1000 \mathrm{~mm}$. The Bago and Maragle State 

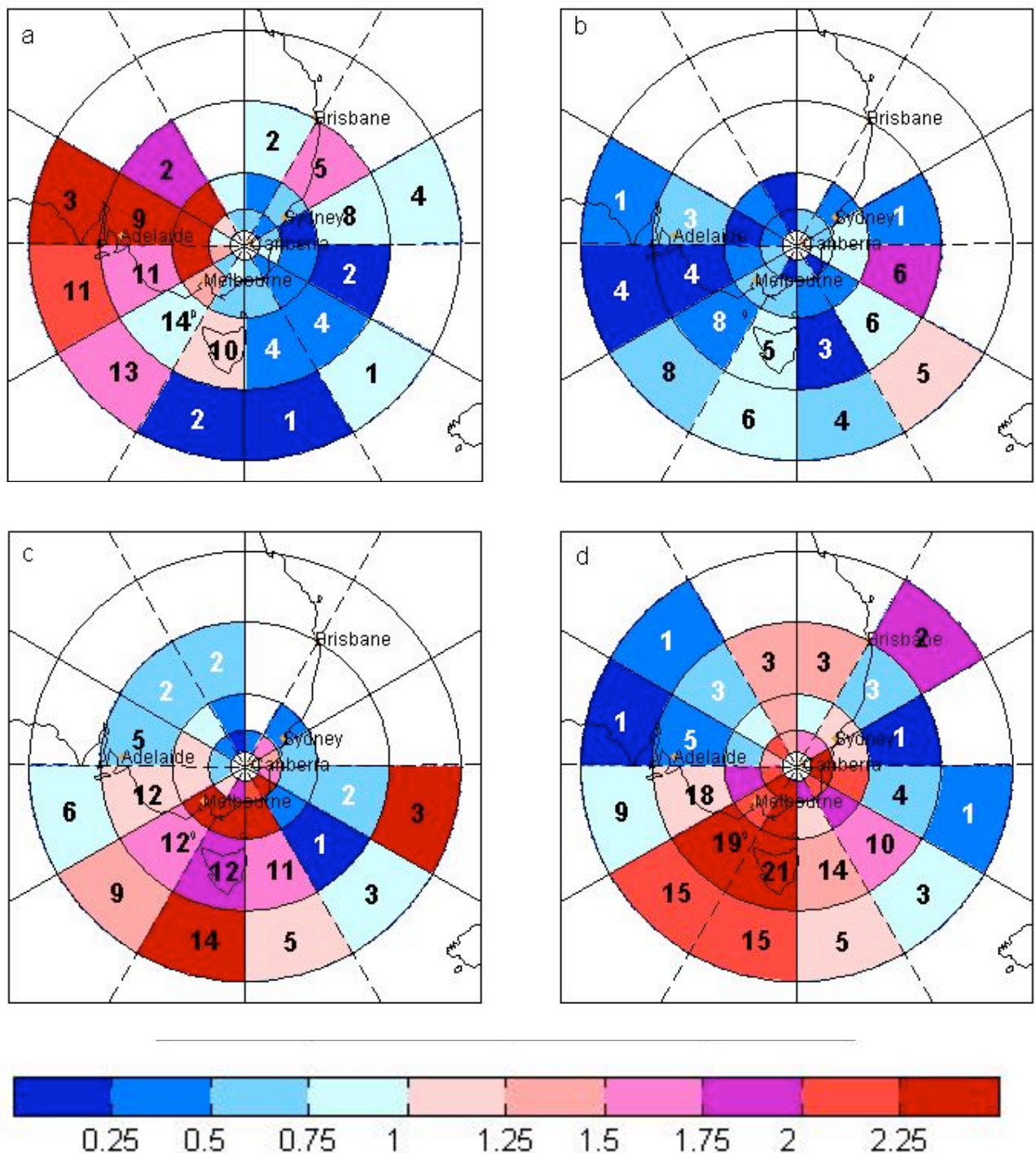

Fig. 5. Frequency of new-particle formation as a function of air mass arrival path for different seasons in July 2005-December 2006. Top left: Dec-Feb; top right: Mar-May; bottom left: Jun-Aug; bottom right: Sep-Nov. The figure inside each sector is the number of days with observed new-particle formation events for air masses that traveled through that particular sector $\left(n_{f}\right)$. For each sector, the color indicates the ratio $r=n_{f} / n_{n}$ where $\mathrm{n}_{n}$ is the number of days with no clear event.

Forests are adjacent to the south west slopes of southern New South Wales and the 48400 ha of native forest have been managed for wood production for over 100 years. Meteorological and flux measurements are carried out on a 70-m tall tower inside and above the forest (Leuning et al., 2005).

Figure 1 presents the major vegetation groups in Australia. Vegetation within $500-1500 \mathrm{~km}$ of our aerosol measurement site in Tumbarumba falls into three main categories: dense native forests mainly on cool mountains up to $1-2 \mathrm{~km}$ high, agricultural fields dotted with Eucalypt woodlands on warmer lowlands, and dry grassland plains.

\subsection{Aerosol concentration and formation of new parti- cles}

The total concentration of ultrafine aerosol particles (lower detection limit $\sim 14 \mathrm{~nm}$ ) was measured above the forest with a condensational particle counter (CPC), TSI model 3010, at the height of $70 \mathrm{~m}$ on the tower. We detected new particle formation by measuring size distributions of air ions (naturally charged clusters and aerosol particles) with an Air Ion Spectrometer (AIS). The AIS (Airel Ltd., Estonia) measures the mobility distribution of both negative and positive air ions in the range of 2.4 to $0.0075 \mathrm{~cm}^{2} \mathrm{~V}^{-1} \mathrm{~s}^{-1}$. This corresponds to a diameter range of approximately 0.34 to $40 \mathrm{~nm}$. Although the AIS only observes charged particles, in field conditions 

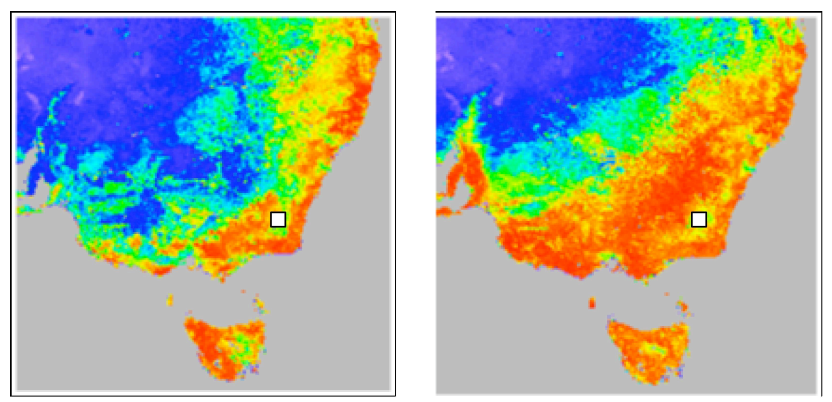

Fig. 6. Monthly average NDVI (Normalized Difference Vegetation Index) in South-East Australia in January (left) and October (right) 2005. The white square indicates the approximate location of Tumbarumba. The NDVI product used here was a subset of the Seawifs Global Monthly “4 km” data $\left(2.5^{\prime}, 0.0416667^{\circ}\right)$. http://oceancolor. gsfc.nasa.gov/REPROCESSING/SeaWiFS/R2/sea_tech.html

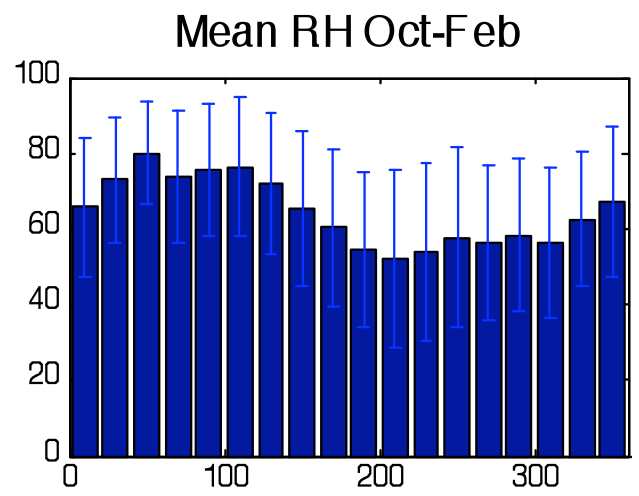

Fig. 7. Average relative humidity as a function of wind direction measured in Tumbarumba in summertime.

the charge balance of atmospheric particles ensures that the formation events observed for charged particles in a particular size range occur for neutral particles as well. The charged fraction is approximately $10 \%$ so there are usually about 10 times more neutral particles than charged ones (Hirsikko et al., 2007).

The classification and analysis of NPF events was presented in Suni et al. (2008). In this paper, we use only events classified as normal. This class includes events where particles start forming in daytime in the cluster ion sizes $(<1.8 \mathrm{~nm})$ and grow by condensation all the way to the Aitken mode $(25-100 \mathrm{~nm})$. We do not take into account interrupted, Aitken, or nocturnal formation (Suni et al., 2008). Nocturnal formation events look completely different from daytime formation events. Therefore, it is likely that they are related to different processes and source vapors than daytime events.

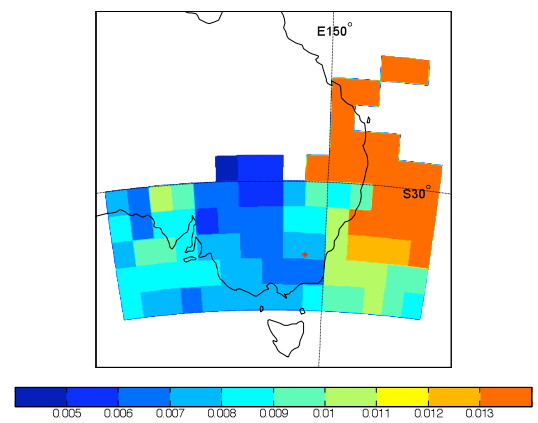

Fig. 8. Average absolute humidity $\left(\mathrm{g} \mathrm{m}^{-3}\right)$ at different points of the air mass trajectories for the whole measuring period. The absolute humidity is approximately double above the Pacific Ocean in the east compared to the Southern Ocean.
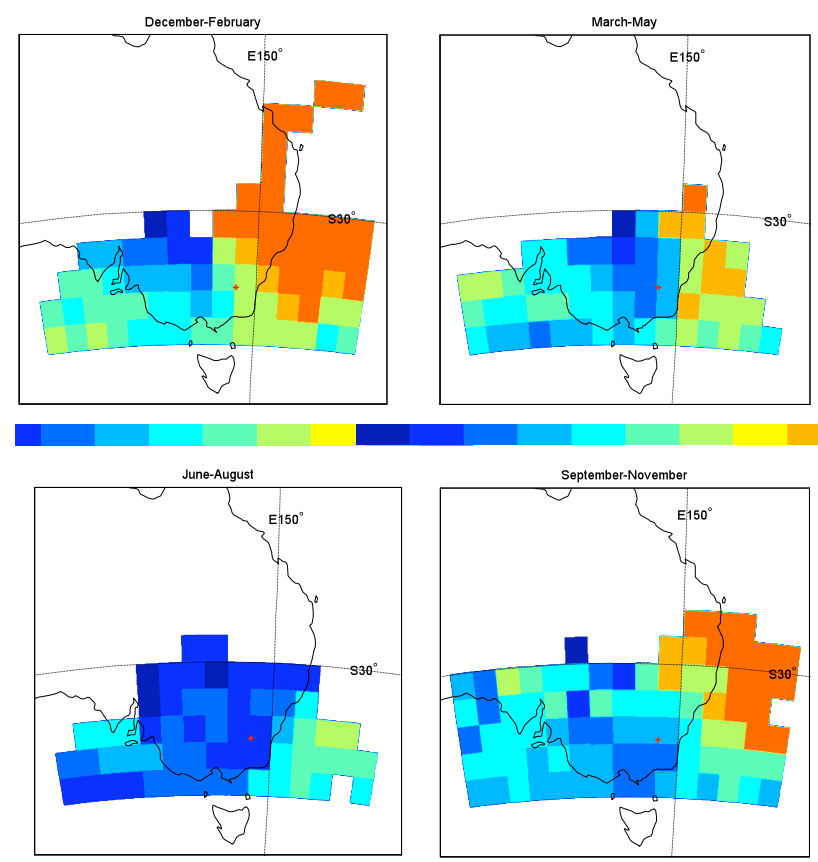

0.004

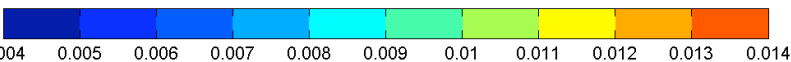

Fig. 9. Average absolute humidity $\left(\mathrm{g} \mathrm{m}^{-3}\right)$ at different points of the air mass trajectories for different seasons. The absolute humidity for different seasons is approximately double above the Pacific Ocean in the east compared to the Southern Ocean in all seasons.

\subsection{VOC measurements}

Ambient concentrations of VOCs in the tall Eucalypt forest in Tumbarumba and in other vegetation types in surrounding areas within a radius of $1000 \mathrm{~km}$ were sampled on stainless steel adsorbent tubes filled with Tenax-TA and Carbopack-B to catch both monoterpenes and isoprene. In front of each tube we used a copper mesh coated with $\mathrm{MnO}_{2}$ to destroy ozone and prevent further oxidizing reactions inside the tube (Calogirou et al., 1996; Helmig, 1997). 


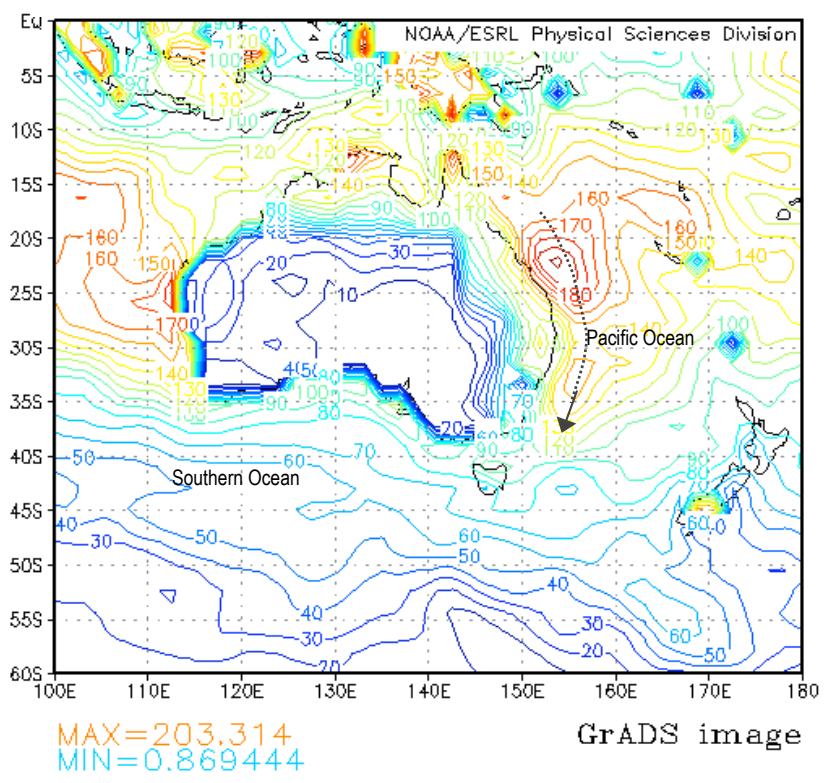

Fig. 10. Average latent heat flux in and near Australia in summer months Dec-Feb 2005-2006. The arrow shows the location of the East Australian Current. NCEP Reanalysis data provided by the NOAA/OAR/ESRL PSD, Boulder, Colorado, USA, from their Web site at http://www.cdc.noaa.gov/

In Tumbarumba, the tubes were elevated to $1-5$ heights in the canopy $(4-40 \mathrm{~m})$ by means of a pulley system. The number of heights depended on the number of Tenax tubes available on each visit to the station, but we always used at least the height of $40 \mathrm{~m}$. During field trips further away, we used a customized 4WD with a portable meteorological measurement system and a 1.5-m stand and helium balloons for elevating the sample tubes and a Vaisala RH/T sensor to varying canopy heights. Flow through the tube was measured at the inlet and set to $80-100 \mathrm{ml} \mathrm{min}^{-1}$. The measurement time was 30-90min allowing 2.4 to 91 of air to flow through the tubes. All the samples were analyzed at the Finnish Meteorological Institute with a GC/MS (gas chromatograph/mass spectrometer). A detailed description of the analysis is given by Hakola et al. (2006).

We made two field trips to surrounding areas, one in April and one in October 2006, in order to measure VOC emissions and to detect differences in the emitted quantities and spectra in the dominant ecosystems around South-East Australia. In Tumbarumba, we took VOC samples in May-July and November 2006 and in February-March 2007, corresponding to Southern Hemisphere winter, spring, and summer, respectively.

\subsection{Trajectory analysis}

To analyse the source and transport pathways of air masses arriving at Tumbarumba, we analysed back trajectories for the measurement period with the HYSPLIT 4 model, devel- oped by NOAA/ARL (Draxler and Hess, 2004). The back trajectories were calculated $96 \mathrm{~h}$ backwards in time at a 70 $\mathrm{m}$ arrival height above ground level hourly from 08:00 to 16:00 LT to include the main part of most particle formation events. Elevation of the air parcel, mixed layer depth (Mld), as well the air parcel properties along the trajectory such as relative humidity $(\mathrm{RH})$, ambient temperature $(T)$, and rain were calculated by means of HYSPLIT trajectory model using the global FNL archive (http://www.arl.noaa. gov/ss/transport/archives.html). See Sogacheva et al. (2005) for more details on the trajectory calculation process.

The area within a radius of $1500 \mathrm{~km}$ around Tumbarumba was divided into $12 \times 4$ sectors and characterized according to its dominant vegetation. We also calculated the distance and the azimuth angle from Tumbarumba for each trajectory at $-6,-12,-24,-48,-72$, and $-96 \mathrm{~h}$ from their arrival time.

\section{Results and discussion}

Most NPF events took place when local wind direction was from $260^{\circ}$ to $280^{\circ}$ (Fig. 2), the agricultural/pasture lowland direction (Fig. 1). This was close to the wind direction $\left(200^{\circ}-220^{\circ}\right)$ that produced the highest number concentrations of newly formed particles (Fig. 3). NPF did not occur when wind was coming from $30^{\circ}$ to $60^{\circ}$ although this was not an infrequent wind direction (Fig. 2). This is the direction largely composed of native grasslands and minimally modified pastures, although agricultural and native woodland areas also occur. Australia's largest city, Sydney, along with a coal mine in Newcastle, is in this direction, albeit several hundreds of kilometers away from Tumbarumba.

To further investigate this phenomenon, we looked at back trajectories of the air masses up to $96 \mathrm{~h}$ prior to their arrival at Tumbarumba. Because air masses move mostly from west to east and tend to turn left in the Southern Hemisphere, the majority of air masses arriving at Tumbarumba originated south from Australia, usually above the Southern Ocean. From there, they either arrived at Tumbarumba crossing the southern coast or traveled around the South-East corner of Australia and approached Tumbarumba from the Pacific Ocean. Air masses originating in the continental Australia passed Tumbarumba from the north.

We divided the area within a radius of $1500 \mathrm{~km}$ surrounding Tumbarumba to $4 \times 12$ sectors and calculated $r$, the ratio of event days to days with no clear event for each sector (Fig. 4). Confirming the local wind findings, this analysis showed that a day with NPF was more frequent than a day with no clear event (average $r=1.53$ per sector) when air was coming from the Southern Ocean in the west and south-west during the whole measuring period (Fig. 4) and also looking at different seasons separately (Fig. 5 and Table 1). On the other hand, a day with no clear event was more frequent than an NPF day (average $r=0.78$ per sector) when the air 

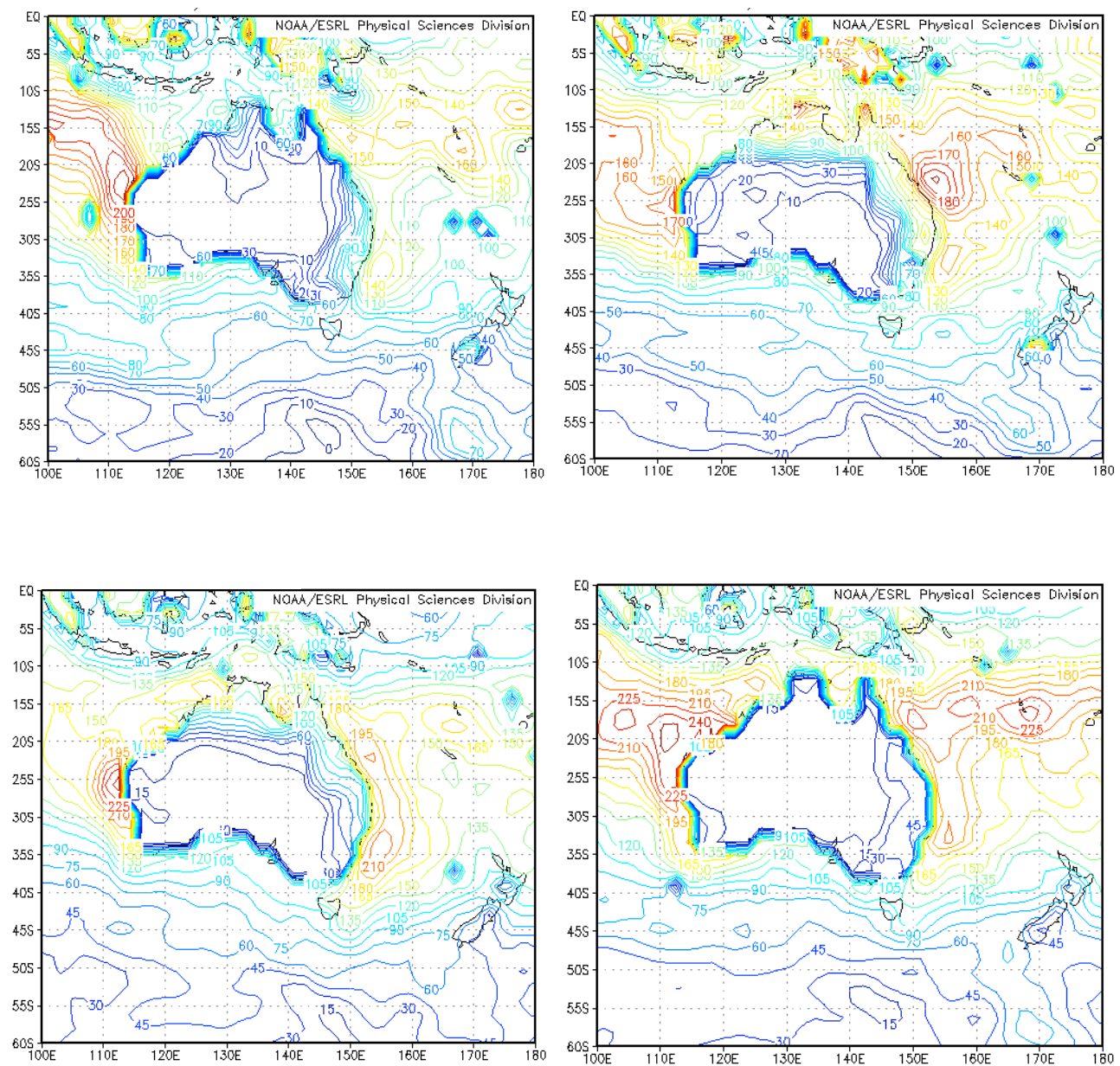

Fig. 11. Average latent heat flux in and near Australia in different seasons. Top left: Dec-Feb; top right: Mar-May; bottom left: Jun-Aug; bottom right: Sep-Nov. NCEP Reanalysis data provided by the NOAA/OAR/ESRL PSD, Boulder, Colorado, USA, from their Web site at http://www.cdc.noaa.gov/.

Table 1. Statistical significance of the difference between average event probabilities per sector (EP) in the south-west and east according to the binomial test.

\begin{tabular}{lllll}
\hline Measurement period & Compass directions compared & $\begin{array}{l}\text { Average EP per sector in the } \\
\text { west/south-west vs. east }\end{array}$ & Average EP difference (\%) & Confidence level \\
\hline All (Fig. 2) & $180^{\circ}-240^{\circ}$ vs. $60^{\circ}-120^{\circ}$ & 0.60 vs. 0.44 & +36 & $p<0.002$ \\
Summer (Fig. 5a) & $210^{\circ}-270^{\circ}$ vs. $60^{\circ}-150^{\circ}$ & 0.62 vs. 0.45 & +38 & $p<0.02$ \\
Autumn (Fig. 5b) & $210^{\circ}-240^{\circ}$ vs. $90^{\circ}-150^{\circ}$ & 0.29 vs. 0.57 & -49 & $p<0.0004$ \\
Winter (Fig. 5c) & $180^{\circ}-240^{\circ}$ vs. $90^{\circ}-150^{\circ}$ & 0.67 vs. 0.45 & +49 & $p<0.02$ \\
Spring (Fig. 5d) & $180^{\circ}-240^{\circ}$ vs. $60^{\circ}-150^{\circ}$ & 0.65 vs. 0.46 & +41 & $p<0.05$ \\
\hline
\end{tabular}

originated in the easterly and south-easterly directions above the Pacific Ocean (Fig. 4). From these areas, the air masses turn left and reach Tumbarumba from the north-east as is evident in the local wind direction measurements (Fig. 2). Converted to average event probability per sector $(\mathrm{EP}=r /(r+1))$, during the whole measuring period the Southern Oceanic air masses produced on average $36 \%$ more events per sector than the Pacific ones (Fig. 4). In summer, winter, and spring, EP in the Southern Ocean direction was $38 \%$ to $49 \%$ higher than EP in the Pacific direction (Table 1). The only exception was autumn when daytime event frequency had a minimum and the main mechanism producing new particles was intensive nocturnal aerosol formation (Suni et al., 2008). 
Table 2. Average concentrations of dominant biogenic VOCs $\left(\mathrm{ng} \mathrm{m}^{-3}\right)$ at $10 \mathrm{~m}$ and $40 \mathrm{~m}$ in Tumbarumba in winter, spring, and summer. Unless all measurements were bdl, bdl have been replaced by half the species-specific detection limit.

\begin{tabular}{|c|c|c|c|c|c|c|}
\hline Species & $\begin{array}{l}\text { Winter }(N=5) \\
4 \mathrm{~m}\end{array}$ & $\begin{array}{l}\text { Winter } \\
(N=18) \\
40 \mathrm{~m}\end{array}$ & $\begin{array}{l}\text { Spring } \\
(N=13) \\
10 \mathrm{~m}\end{array}$ & $\begin{array}{l}\text { Spring }(N=21) \\
40 \mathrm{~m}\end{array}$ & $\begin{array}{l}\text { Summer }(N=5) \\
10 \mathrm{~m}\end{array}$ & $\begin{array}{l}\text { Summer } \\
(N=6) \\
40 \mathrm{~m}\end{array}$ \\
\hline a-pinene & $50 \pm 38$ & $80 \pm 93$ & $196 \pm 81$ & $170 \pm 92$ & $336 \pm 236$ & $208 \pm 97$ \\
\hline b-pinene & $24 \pm 22$ & $56 \pm 90$ & $59 \pm 78$ & $53 \pm 74$ & $91 \pm 76$ & $45 \pm 29$ \\
\hline 1,8-cineol & $58 \pm 31$ & $196 \pm 163$ & $363 \pm 453$ & $280 \pm 364$ & $907 \pm 919^{1}$ & $697 \pm 744^{1}$ \\
\hline Isoprene & bdl & $16 \pm 21$ & $1004 \pm 882$ & $912 \pm 916$ & $786 \pm 481$ & $913 \pm 644$ \\
\hline MBO & bdl & $23 \pm 44$ & $176 \pm 189$ & $128 \pm 132$ & $54 \pm 95$ & $45 \pm 79$ \\
\hline camphene & bdl & bdl & $7 \pm 7$ & $22 \pm 66$ & bdl & bdl \\
\hline sabinene & bdl & $5 \pm 7$ & $4 \pm 7$ & $5 \pm 8$ & $11 \pm 15$ & $7 \pm 2$ \\
\hline 3-carene & bdl & bdl & $11 \pm 13$ & $10 \pm 10$ & $30 \pm 52$ & $27 \pm 40$ \\
\hline limonene & bdl & bdl & $51 \pm 48$ & $48 \pm 36$ & $61 \pm 67$ & $44 \pm 31$ \\
\hline
\end{tabular}

1 These columns include one late evening measurement at 22:00 standard time. Values similar to daytime numbers except for eucalyptol that had 2487 and $2177 \mathrm{ng} \mathrm{m}^{-3}$ at $10 \mathrm{~m}$ and at $40 \mathrm{~m}$, respectively.

Table 3. Average concentrations of dominant biogenic VOCs $\left(\mathrm{ng} \mathrm{m}^{-3}\right)$ above various vegetation within $1000 \mathrm{~km}$ around Tumbarumba during a field campaign in April 2006.

\begin{tabular}{lllllllll}
\hline & $\begin{array}{l}\text { Grassland } \\
\text { Maude } \\
\text { Road }\end{array}$ & $\begin{array}{l}\text { Eucalypt Brind- } \\
\text { abella } \\
\text { mountains }\end{array}$ & $\begin{array}{l}\text { Semiurban mixed } \\
\text { Eucalypt/pasture } \\
\text { Broken Hill }\end{array}$ & $\begin{array}{l}\text { Eucalypt } \\
\text { Tumba- } \\
\text { rumba }\end{array}$ & $\begin{array}{l}\text { Mixed pasture/ } \\
\text { Eucalypt } \\
\text { Balranald }\end{array}$ & $\begin{array}{l}\text { Dry } \\
\text { Mundi Mundi }\end{array}$ & $\begin{array}{l}\text { Mixed } \\
\text { Eucalypt/ } \\
\text { pine Tumut }\end{array}$ & $\begin{array}{l}\text { Mixed } \\
\text { pasture/ } \\
\text { Eucalypt } \\
\text { Griffith }\end{array}$ \\
\hline isoprene & - & - & - & - & - & - & - \\
MBO & - & 355 & - & 158 & 28 & 51 & - \\
a-Pinene & - & 4695 & - & - & - & - & - \\
b-Pinene & 11 & 6294 & 6 & - & - & - & - & - \\
3-Carene & 118 & - & - & - & - & - & - \\
Limonene & 925 & - & 506 & 58 & 254 & - & - & - \\
1,8-Cineol & 110 & 20 & 267 & - & - & 35 \\
\hline
\end{tabular}

Vegetation in South-East Australia varies greatly with more forested areas to the east than to the west of Tumbarumba (Fig. 1). The lack of comprehensive VOC measurements in the area is a challenge to any study involving atmospheric chemistry, and our two field trips around Victoria and New South Wales were the first attempts to fill this gap in knowledge. We could not find a systematic, consistent difference between the east and west directions or among different vegetation types - the only consistent feature was great variability in VOC composition (Tables 2-4). However, satellite measurements of the Normalized Differential Vegetation Index (NDVI) showed that within a few hundred kilometers from Tumbarumba no clear difference in photosynthetic activity existed between the north-east and the south-west direction (Fig. 6). The production rates of many VOCs are closely related to photosynthesis and we concluded, therefore, that there were no grounds to suggest the overall VOC load would be clearly different in the east and the west, al- though the composition of VOCs obviously varied in different vegetation areas.

With no evident difference in the amount of organic precursor vapors between the north-east and south-west directions, we postulated that the frequent new-particle formation in the westerly and south-westerly trajectories could be connected with favorable meteorological conditions such as clear and dry weather. In order to test this, we compared relative humidity $(\mathrm{RH})$ and local wind direction in Tumbarumba and indeed found that during peak NPF in spring and summer, average RH was approximately $75 \%$ in the north-easterly winds and only about $55 \%$ in the southwesterly winds (Fig. 7). Based on total ultrafine particle concentration measurements, the air in Tumbarumba is usually always clean regardless of the wind direction, so anthropogenic pollution from any direction is minimal (Suni et al., 2008). Furthermore, tracing the back trajectory properties we found that, on average, the Pacific Ocean produced 
Table 4. Average concentrations of dominant biogenic VOCs $\left(\mathrm{ng} \mathrm{m}^{-3}\right)$ around Tumbarumba during a field campaign in October 2006.

\begin{tabular}{lllllll}
\hline $\mathrm{ng} / \mathrm{m}^{3}$ & $\begin{array}{l}\text { Dry grass- } \\
\text { land } \\
\text { Mundi } \\
\text { Mundi }\end{array}$ & $\begin{array}{l}\text { Acacia } \\
\text { Bourke }\end{array}$ & $\begin{array}{l}\text { Eucalypt } \\
\text { Rosehill }\end{array}$ & $\begin{array}{l}\text { Pine } \\
\text { Hidden } \\
\text { Valley }\end{array}$ & $\begin{array}{l}\text { Eucalypt } \\
\text { Oberon }\end{array}$ & $\begin{array}{l}\text { Eucalypt } \\
\text { Mt Spring }\end{array}$ \\
\hline isoprene & - & 703 & 747 & 1044 & 402 & 123 \\
MBO & - & - & - & - & 644 & 16 \\
a-Pinene & - & 17 & 97 & 95 & 277 & 15 \\
b-Pinene & - & - & - & - & 240 & - \\
3-Carene & - & - & - & - & - & - \\
Limonene & - & 53 & - & - & - & - \\
1,8-Cineol & 11 & 30 & 436 & 73 & 148 & 169 \\
\hline
\end{tabular}
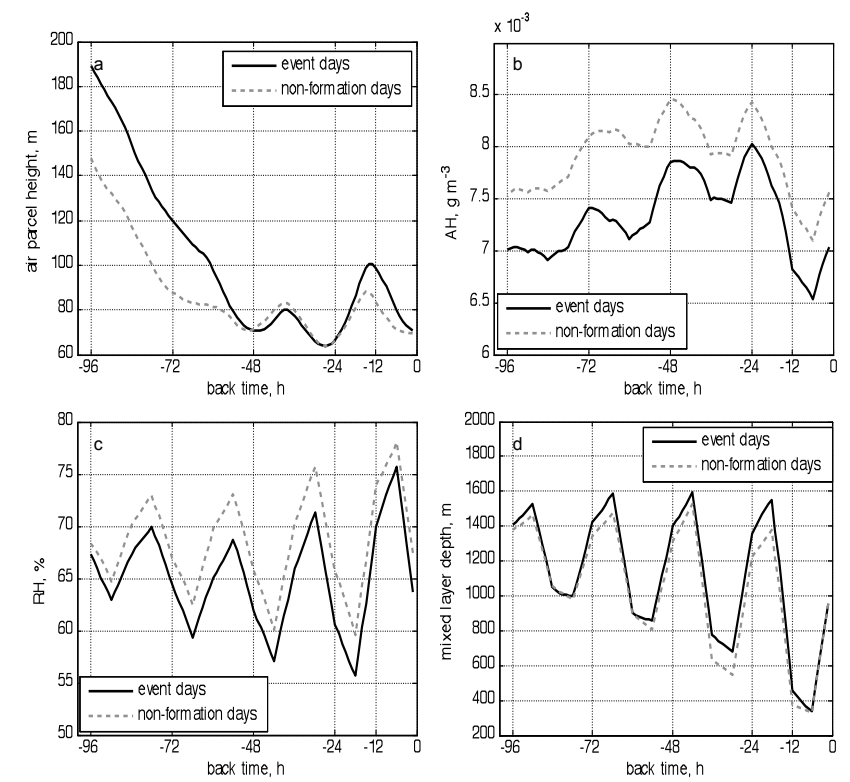

Fig. 12. Meteorological variables along the trajectories. (a) Air parcel height, (b) absolute humidity, (c) relative humidity, and (d) mixed layer depth for new-particle formation events and nonformation and unclear days for the whole period.

significantly more humidity than the Southern Ocean (Fig. 8; division to seasons in Fig. 9). This was clearly because the latent heat flux (LE) was almost double above the Pacific Ocean compared to that above the Southern Ocean in summer (Fig. 10) and consistently in all seasons (Fig. 11). One explanation for this difference in LE is the warm tropical East Australian Current sweeping the eastern coast of Australia in the Pacific Ocean (Fig. 10). The warm current provides heat and high absolute humidity at the eastern coast of Australia. When significantly colder air with lower absolute humidity flows from the south and mixes with the warm, humid air at the sea surface, a strong latent heat flux forms between the surface and the air above it. The relative humidity of this air mass increases further when it rises along the coastal mountains on its way to Tumbarumba. Contrary to the VOC comparison, the difference in RH between the south-west and north-east directions was absolutely clear and easily observable. Humidity was the only variable evidently in tune with the NPF trend but this does not mean that other factors could not have contributed significantly, too.

Field evidence points strongly towards a suppressing effect of humidity on aerosol formation above forests (Nilsson et al., 2001; Buzorius et al., 2001; Suni et al., 2008; Kesselmeier and Staudt, 1999). Solar radiation and water vapor are involved in the production of $\mathrm{OH}$ which, in turn, is instrumental in converting $\mathrm{SO}_{2}$ into sulfuric acid $\left(\mathrm{H}_{2} \mathrm{SO}_{4}\right)$, an important component in cluster activation and initial steps of particle growth (Hyvönen et al., 2005; Kulmala et al., 2006). However, because high humidity leads to cloudiness, a maximum production level should exist between low and high humidity (Hyvönen et al., 2005). An increase in absolute humidity will at first enhance sulfuric acid formation, but this will decline after the appearance of clouds at high RH (Hyvönen et al., 2005).

Laboratory studies have given seemingly contradictory results of the effect of water vapor on the chemical reactions involved in secondary aerosol formation from the ozonolysis of monoterpenes $\left(\mathrm{C}_{10} \mathrm{H}_{16}\right)$ (Bonn et al., 2002; Jonsson et al., 2006). Although homogeneous nucleation from the ozonolysis of monoterpenes is unlikely in atmospheric conditions (Bonn et al., 2003), the qualitative conclusions drawn about monoterpene nucleation are likely to apply also to the more probable sesquiterpene $\left(\mathrm{C}_{15} \mathrm{H}_{24}\right)$ nucleation because the reacting functional groups of mono- and sesquiterpenes are similar. A clear negative effect on aerosol yield was observable from the ozonolysis of exocyclic monoterpenes $(\beta$ pinene and sabinene) but a lesser, at low concentrations even positive, effect on endocyclic monoterpenes $\alpha$-pinene and $\Delta_{3}$-carene) (Bonn et al., 2002). The authors suggested that water vapor (in addition to alcohols and acids) competed with the carbonyl - stabilized Criegee intermediate - reactions 
that they believed initiated the nucleation. An inhibiting effect of water vapour was also observable on sesquiterpene ozonolysis (Bonn et al., 2003). On the contrary, another study found a clear increase in aerosol volume and number concentration with RH throughout the range of $2-85 \%$ for limonene, $\Delta_{3}$-carene, and $\alpha$-pinene, with concentrations closer to ambient (Jonsson et al., 2006). According to this study, there is probably a mechanistic explanation according to which the presence of water increases the yield of lowvolatility compounds in terpene oxidation but a further study showed that except at sub-zero temperatures, this physical mechanism cannot account for the observations alone (Jonsson et al., 2008a, b). Instead, water also clearly affects the chemistry or rate of reactions involved (Jonsson et al., 2008a, b).

The explanation behind these opposite observations (Bonn et al., 2002, 2003; Jonsson et al., 2006, 2008a, b) could be that different mechanisms are responsible for nucleation at different concentrations of organic reactants. Also, different types of $\mathrm{OH}$ scavengers used to remove the effect of $\mathrm{OH}$ on monoterpene ozonolysis can influence the results of laboratory experiments (Jonsson et al., 2008a). Yet another potential explanation is that the key reactions for nucleation at low concentrations (even between two organic molecules) are catalyzed by water molecules rather than, or in addition to, involving them as reactants. The contrasting field and laboratory observations emphasize the complexity involved in the interactions among water vapor and the meteorology and chemistry of aerosol formation.

The dominant biogenic VOC in Tumbarumba and surrounding areas were 1,8-cineol (eucalyptol), isoprene, $\alpha$ pinene, 2-methyl-3-buten-2-ol (MBO), and $\beta$-pinene, as shown in Tables 2-4. The concentrations were high compared to those in the boreal zone (Hakola et al., 2003). Pinenes are known to contribute to secondary aerosol formation (Bonn et al., 2002), and MBO is a weak secondary aerosol producer (Carrasco et al., 2007). Both are common in the boreal zone (Hakola et al., 2003). We found especially high concentrations of limonene $400 \mathrm{~km}$ west from Tumbarumba (Table 2) that could contribute to the high aerosol concentrations coming from the west and south-west. The aerosol yield of limonene ozonolysis is many times higher than that of pinene oxidation (Jonsson et al., 2006; Vartiainen et al., 2006). Another factor favoring this wind direction is that on days with NPF, air masses arrived from a higher altitude than on days with no NPF (Fig. 12a). This could add to the relative dryness of these westerly/south-westerly trajectories. Event-day trajectories in general also had lower absolute and relative humidity than non-event-day trajectories (Fig. 12b and c) along with higher boundary layers (BL) (Fig. 12d). In addition to total energy input, higher BL is the result of lower latent heat flux that leaves more energy to the sensible heat flux which creates the BL.

\section{Conclusions}

According to our analysis of 96-h back trajectories, formation of new particles was most frequent in the dry westerly and south-westerly air masses. According to NDVI measurements, photosynthesis was not significantly higher in this direction compared to the north-east direction. It is unlikely, therefore, that differences in photosynthesis-derived organic precursor emissions would have been significant enough to lead to the clear difference in NPF frequency between these two directions. Instead, the high evaporation rates above the Pacific Ocean resulted in humid winds from the north-east and effective suppression of new-particle formation in the forest hundreds of kilometers inland. No other factor varied as significantly in tune with new-particle formation as humidity. More field measurements need to be made to assess the role of VOCs in different parts of South-East Australia but, based on current evidence, humidity variation has by far the greatest correlation with NPF variation.

Combining these findings with earlier results of the positive effect of Arctic and polar air masses on aerosol formation in the Nordic boreal zone, we conclude that the cold polar oceans provide clean and dry air which, upon mixing with terpene emissions from vegetation, produces frequent newparticle formation in near-coastal forests in the Northern and Southern Hemispheres. Warm oceans, on the contrary, produce clean but humid air that effectively suppresses terrestrial biogenic new-particle formation even in the presence of high concentrations of precursor vapors.

Acknowledgements. This work was supported by the Academy of Finland, Maj and Tor Nessling Foundation, the Centennial Foundation of Helsingin Sanomat, CSIRO, the Australian Greenhouse Office's Australian Climate Change Science Program, and the New South Wales Environmental Trusts. We kindly acknowledge Ray Leuning for his insightful comments and S. Zegelin, D. Hughes, M. Kitchen and R. Hurley at CSIRO for their technical support. The authors have no competing financial interests. All the authors have agreed to all the content in the manuscript, including the data as presented.

Edited by: V.-M. Kerminen

\section{References}

Anttila, T. and V.-M. Kerminen: Modeling study on aerosol dynamical processes regulating new particle and $\mathrm{CCN}$ formation at clean continental areas, Geophys. Res. Lett., 35, L07813, doi:10.1029/2008GL033371, 2008.

Atkinson, R.: Atmospheric chemistry of VOCs and $\mathrm{NO}_{\mathrm{x}}$, Atmosph. Env., 34, 2063-2101, 2000.

Baker, M. B. and Peter, T.: Small-scale cloud processes and climate, Nature, 451, 299-300, 2008.

Bonn, B. and Moortgat, K.: Sesquiterpene ozonolysis: Origin of atmospheric new particle formation from biogenic hydrocarbons, Geophys. Res. Lett., 30, 1585, doi:10.1029/2003GL017000, 2003. 
Bonn, B., Schuster, G., and Moortgat, G. K.: Influence of Water Vapor on the Process of New Particle Formation during Monoterpene Ozonolysis, J. Phys. Chem. A, 106, 2869-2881, 2002.

Buzorius, G., Rannik, Ü., Nilsson, D., and Kulmala, M.: Vertical fluxes and micrometeorology during aerosol particle formation events, Tellus B 53, 394-405, 2001.

Calogirou, A., Richter Larsen, B., Brussol, C., Duane, M., and Kotzias, D.: Decomposition of terpenes by ozone during sampling on Tenax., Anal. Chem. 68, 1499-1506, 1996.

Calogirou, A., Richter Larsen, B., and Kotzias, D.: Gas-phase terpene oxidation products: a review, Atmosph. Env., 33, 14231439, 1999.

Carrasco, N., Doussin, J. F., O'Connor, M., Wenger, J. C., PicquetVarrault, B., Durand-Jolibois, R., and Carlier, P. : Simulation Chamber Studies of the Atmospheric Oxidation of 2-Methyl-3Buten-2-ol: Reaction with Hydroxyl Radicals and Ozone Under a Variety of Conditions, J. Atmos. Chem. 56, 33-55, 2007.

Clement, A. C., Burgman, R., and Norris, J. R.: Obser vational and model evidence for positive low-level cloud feedback. Science, 325, 460-464, doi:10.1126/science.1171255, 2009.

Draxler, R. R. and Hess, G. D.: Description of the HYSPLIT_4 Modeling System, NOAA Technical Memorandum ERL ARL224, 2004

Hakola, H., Tarvainen, V., Bäck, J., Rinne, J., Ranta, H., Bonn, B., and Kulmala, M.: Seasonal variation of mono- and sesquiterpene emission rates of Scots pine, Biogeosciences, SRef-ID: 17264189/bg/2006-3-93, 93-101, 2006.

Hakola, H., Tarvainen, V., Laurila, T., Hiltunen, V., Hellén, H., and Keronen, P.: Seasonal variation of VOC concentrations above a boreal coniferous forest, Atmos. Env. 37, 1623-1634, 2003.

Helmig, D.: Ozone Removal Techniques in the Sampling of Atmospheric Volatile. Organic Trace Gases, Atmos. Environ. 31, 3635-3651, 1997.

Hirsikko, A., Bergman, T., Laakso, L., Dal Maso, M., Riipinen, I., Hõrrak, U., and Kulmala, M.: Identification and classification of the formation of intermediate ions measured in boreal forest, Atmos. Chem. Phys., 7, 201-210, 2007,

http://www.atmos-chem-phys.net/7/201/2007/.

Hyvönen, S., Junninen, H., Laakso, L., Dal Maso, M., Grönholm, T., Bonn, B., Keronen, P., Aalto, P., Hiltunen, V., Pohja, T., Launiainen, S., Hari, P., Mannila, H., and Kulmala, M.: A look at aerosol formation using data mining techniques, Atmos. Chem. Phys. 5, 3345-3356, 2005.

Jonsson, Å.M., Hallquist, M., and Ljungström, E.: Impact of Humidity on the Ozone Initiated Oxidation of Limonene, $\Delta^{3}$ Carene, and $\alpha$-Pinene, Environ. Sci. Technol. 40, 188-194, 2006.

Jonsson, Å.M., Hallquist, M., and Ljungström, E.: Influence of OH Scavenger on the Water Effect on Secondary Organic Aerosol Formation from Ozonolysis of Limonene, $\Delta^{3}$-Carene, and $\alpha$ Pinene, Environ. Sci Technol. 42, 5938-5944, 2008a.

Jonsson, Å. M., Hallquist, M., and Ljungström, E.: The effect of temperature and water on secondary organic aerosol formation from ozonolysis of limonene, $\Delta^{3}$-carene and $\alpha$-pinene, Atmos. Chem. Phys., 8, 6541-6549, 2008b, http://www.atmos-chem-phys.net/8/6541/2008/.

Kerminen, V.-M., Lihavainen, H., Komppula, M., Viisanen, Y., and Kulmala, M.: Direct observational evidence linking atmospheric aerosol formation and cloud droplet activation, Geophys. Res. Lett. 32, L14803, doi:10.1029/2005GL023130, 2005.
Kesselmeier, J. and Staudt, M.: Biogenic Volatile Organic Compounds (VOC): An Overview on Emission, Physiology and Ecology, J. Atmos. Chem. 33, 23-88, 1999.

Kulmala, M., Lehtinen, K. E. J., and Laaksonen, A.: Cluster activation theory as an explanation of the linear dependence between formation rate of $3 \mathrm{~nm}$ particles and sulphuric acid concentration, Atmos. Chem. Phys. 6, 787-793, 2006.

Kulmala, M., Vehkamäki, H., Petäjä, T., Dal Maso, M., Lauri, A., Kerminen, V.-M., Birmili, W., and McMurry, P. H.: Formation and growth rates of ultrafine atmospheric particles: a review of observations, J. Aerosol Sci., 35, 143-176, 2004.

Kurtén, T., Kulmala, M., Dal Maso, M., Suni, T., Reissell, A., Vehkamäki, H., Hari, P., Laaksonen, A., Viisanen, Y., and Vesala, T.: Estimation of different forest-related contributions to the radiative balance using observation in southern Finland, Boreal Env. Res., 8, 275-285, 2003.

Laaksonen, A., Hamed, A., Joutsensaari, J., Hiltunen, L., Cavalli, F., Junkermann, W., Asmi, A., Fuzzi, S., and Facchini, M. C.: Cloud condensation nucleus production from nucleation events at a highly polluted region, Geophys. Res. Lett. 32, L06812, doi:10.1029/2004GL022092, 2005.

Leuning, R., Cleugh, H. A., Zegelin, S., and Hughes, D.: Carbon and water cycles in two contrasting Australian ecosystems: Wet/Dry savannas and cool temperate Eucalyptus forest, Agr. For. Meteor. 129, 151-173, 2005.

Modini, R. L., Ristovski, Z. D., Johnson, G. R., He, C., Surawski, N., Morawska, L., Suni, T., and Kulmala, M.: New particle formation and growth at a remote, sub-tropical coastal location, Atmos. Chem. Phys., 9, 7607-7621, 2009

Nilsson, E. D., Paatero, J., and Boy, M.: Effects of air masses and synoptic weather on aerosol formation in the continental boundary layer, Tellus B 53, 462-478, 2001.

Ristovski, Z. D., Suni, T., Kulmala, M., Boy, M., Meyer, N. K., Duplissy, J., Turnipseed, A. , Morawska, L., and Baltensperger, U. The role of sulphates and organic vapours in new particle formation in a eucalypt forest, Atmos. Chem. Phys. Discuss., 9, 1779317815, 2009.

Sogacheva, L., Dal Maso, M., Kerminen, V.-M., and Kulmala, M.: Probability of nucleation events and aerosol particle concentration in different air mass types arriving at Hyytiälä, southern Finland, based on back trajectories analysis, Boreal Environ. Res., 10, 479-491, 2005.

Spracklen, D. V., Carslaw, K. S., Kulmala, M., Kerminen, V.-M., Mann, G. W., and Sihto, S.-L.: The contribution of boundary layer nucleation events to total particle concentrations on regional and global scales, Atmos. Chem. Phys., 6, 5631-5648, 2006, http://www.atmos-chem-phys.net/6/5631/2006/.

Suni, T., Kulmala, M., Hirsikko, A., Bergman, T., Laakso, L., Aalto, P. P., Leuning, R., Cleugh, H., Zegelin, S., Hughes, D., van Gorsel, E., Kitchen, M., Vana, M., Hõrrak, U., Mirme, S., Mirme, A., Sevanto, S., Twining, J., and Tadros, C.: Formation and characteristics of ions and charged aerosol particles in a native Australian Eucalypt forest, Atmos. Chem. Phys., 8, 129-139, 2008, http://www.atmos-chem-phys.net/8/129/2008/.

Tunved, P., Hansson, H.-C., Kerminen, V.-M., Ström, J., Dal Maso, M., Lihavainen, H,. Viisanen, Y., Aalto, P. P., Komppula, M., and Kulmala, M.: High Natural Aerosol Loading over Boreal Forests, Science, 312, 261-263, doi:10.1126/science.1123052, 2006. 
Vartiainen, E., Kulmala, M., Ruuskanen, T. M., Taipale, R., Rinne, J., and Vehkamäki, H.: Formation and growth of indoor air aerosol particles as a result of d-limonene oxidation, Atmos. Env. 40, 7882-7892, doi:10.1016/j.atmosenv.2006.07.022, 2006.
Wang, J., Lee, Y.-N., Daum, P. H., Jayne, J., and Alexander, M. L.: Effects of aerosol organics on cloud condensation nucleus (CCN) concentration and first indirect aerosol effect, Atmos. Chem. Phys. 8, 6325-6339, 2008 